\title{
The Development of Student Worksheet with SETS Approaches for Train Students' Critical and Creative Thinking Skills
}

\author{
Khoirunnisa $^{1}$, A.Surbakti ${ }^{2}$, Rochmiyati $^{3}$ \\ \{khoirunnisataher@gmail.com ${ }^{1}$, arwinsurbakti@yahoo.com ${ }^{2}$, rochmiyatiazwardi@yahoo.co.id ${ }^{3}$ \} \\ Master of Teaching Primary Education, FKIP Lampung University, Indonesia ${ }^{1}$, \\ Department of Biology Education, FKIP Lampung University, Indonesia ${ }^{2}$, \\ Department of Primary School Teacher Education, FKIP Lampung University, Indonesia ${ }^{3}$
}

\begin{abstract}
This study set out to develop student worksheet with SETS approaches for train students critical and creative thinking skills. The method is research and development ( $R \mathrm{n})$. This research was involves fifth graders in elementary school in Bandar Lampung, Indonesia. It has been conducted on 56 students with purposive sampling technique. Student worksheet have criteria "very complete" and "usable". The scores in experiment was $71,2 \%$ with cat egory "quite effective" higher than control class was $69.2 \%$ that have category "less effective" in creative thinking skills. The scores for critical skills in experiment was $69.2 \%$ with "quite effective" higher than $51 \%$ (other class) with "less effective". Student give responses that they interested in worksheet. Based on the research findings, it shows that student worksheet effectively to train creative and critical thinking of students.
\end{abstract}

Keywords:Creative Thinking Skills; Critical Thinking Skills; Science Environment Technology and Society; Student Activity Sheet

\section{Introduction}

The millennium era is an era where technological developments are very rapid. This requires students to be able face the 21 st century so they can compete in the global era. $21 \mathrm{st}$ century learning must be able to develop competitive skills that focus on skills. Creative thinking can enrich the way of thinking with diverse alternatives [1]. Meanwhile, critical thinking skills are needed by students to develop skills, expand thinking processes, and improve concentration [2]. But in reality, the thinking skills of Indonesian students are still relatively low. It was showed from the results of the 2015 Global Creativity Index (GCI) research that Indonesia ranks 115th out of 139 countries [3]. Furthermore the study that tested the ability to think at a higher level in 2015 showed that 72 field science followed by grade IV elementary school students [4]. Study show that students do not have the creative and critical thinking skills yet. It was supported by the results that there are complaints about the low critical and creative thinking skills possessed by graduates of basic education to tertiary institutions [5]. Other research results also show that the creative skill and concept maximally not implemented due to the teachers do not much time that can train the ability to think creatively and concept understanding [6]. Based of above facts and critical, then theeffort that 
can be done is to provide a learning. The learning approach in question is by applying a SETSbased learning approach.

SETS model is an model that has linkages of learning with real life, which makes students more interested in learning and can lead to meaningful experiences for students. Learning us ing the SETS approach is thought to have a positive effect on students' relationships with in real world and able to encourage students critical to found problem on environment. SETS approach emphasizes learners [7]. The application of SETS in learning aims to develop cognitive skills, affective skills, and psychomotor skills [8]. Therefore, according to [9] learning with the SETS approach must be org anized by integrating various disciplines in order to understand the various relationships that occur between science, the environment, technology, and society, so that it has the effect on critical thinking. Evidenced by SETS approach could train students' logical reasoning, using the questions, and more creative to solve the problems [10].

Based on this, SETS-based learning is needed through the development of appropriate learning resources so that students' creative and critical thinking skills could be trained. One of the learning resource that developed using SETS-based learning approach was LKPD (Student W orksheet). LKPD could be an effective and innovative source of learning because it contains material for learning competencies that must be done [11]. Besides that, LKPD can increase the creativity of students, learning outcomes and involvement in learning activities to be more active [12]. In addition to increasing creativity, LKPD with SETS vision can also choice of [13].

\section{Method}

Development produces namely LKPDbased on the SETS approach. The study was carried out at Bandar Lampung city in Indonesia on August 2019. The population of fifty six students of class V consisting of two clas ses with purposive sampling techniques. The review in this article discusses the validity of LKPD based on the SETS approach. Validation is done for material experts, media experts, linguists, and peer reviewer using a validation sheet instrument. Data obtained through expert validation sheets in the form of quantitative data based on the results of the score statement about the suitability of LKPD and qualitative data obtained based on review on developed LKPD.

The score determined by this formula [14].

$$
N=\frac{R}{S M} X 100 \%
$$

Information:

$\mathrm{N}=$ the percent

$\mathrm{R}=$ raw score

$\mathrm{SM}=$ score maximum

Assessment of material language and peers converted to the final score which could be seen in Table 1 of the instrument validity criteria [15]. 
Table 1. Criteria of Validity by Material Expert, Media, Language, and Peer

\begin{tabular}{cc}
\hline Final Score & Criteria \\
\hline $81 \%-100 \%$ & Very Valid, very complete, can be used \\
\hline $61 \%-80 \%$ & Valid enough, effective enough, can be used with minor improvements \\
\hline $41 \%-60 \%$ & Less valid, less effective, less complete, not for use \\
\hline $21 \%-40 \%$ & Invalid, ineffective, not complete, cannot be used \\
\hline $0 \%-20 \%$ & Very invalid, very ineffective, very incomplete, cannot be used \\
\hline
\end{tabular}

Furthermore, LKPD based on the SETS approach through 19 item.

$$
\mathrm{N}-\text { Gain }=\frac{\text { posttest score }- \text { pretest score }}{\text { maximumscore }- \text { pretest score }}
$$

Classification of Average N-gain from Hake [16].

Table 2. Interpretation

\begin{tabular}{cc}
\hline Average & Interpretation \\
\hline $0,70<\mathrm{N}$-Gain $\leq 1,00$ & High \\
\hline $0,30<\mathrm{N}$-gain $\leq 0,70$ & Sufficient \\
\hline $\mathrm{N}$-Gain $\leq 0,30$ & Low \\
\hline
\end{tabular}

Emotional intelligence could be interpreted by using the interpretation category have shown [17].

Table 3. Interpretation of Effectiveness

\begin{tabular}{cc}
\hline Percentage (\%) & Interpretation \\
\hline$<40$ & Not Effective \\
\hline $40-55$ & Les s \\
\hline $56-75$ & Sufficient \\
\hline$>76$ & Effective \\
\hline
\end{tabular}

\section{Results}

\subsection{Feasibility LKPD SETS approach}

Validation has done by involving validators of material experts, media, languages, and peers. Validation results based on validated aspects are explained in Figure 1. 


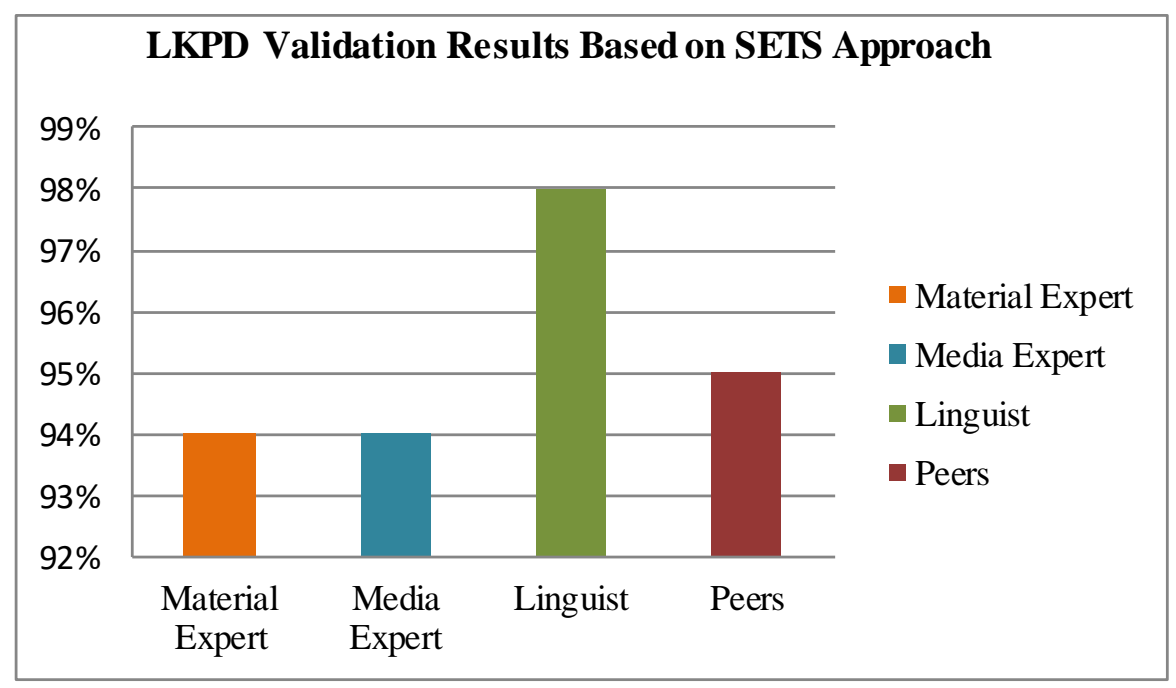

Fig 1. Result of Validity LKPD Based on SET S Approach

Figure 1 shows the overall validator's as sessment of the LKPD based on the SETS approach that was developed with $95.25 \%$ very valid, very complete, and usable. The results of this validation show that the LKPDbased on the SETS approach developed is feasible to use at the implementation step.

The material contained in LKPD is in accordance with the contents of the scientific pers pective. LKPD make students to be active in learning. Furthermore, LKPD is also able to invite students to find information, train students to express opinions and questions, students could motivated to care about the environment, and the material presented can be applied in daily life, and has clear evaluation instructions. Then for the media contained in LKPD in accordance with the ideal LKPD format, because LKPD has been accompanied by a front cover that includes the name of the compiler, students' identities, pre-words, table of contents, LKPD usage instructions, as well as the KI and KD mapping to be achieved, and the availability of sufficient space for students to fill in answers, and bibliography. Furthermore, the language contained in LKPD is in line between language and the level of able to motivate students to learn, and be able to create interactive communication. Then the assessment results of the developed LKPD colleagues are in accordance with the translation of LKPD material with KI and KD.LKPD is also affective, cognitive, and psychomotor development of students and integrate with daily is sues and problems.

\subsection{Effectiveness of LKPD bas ed on SETS approach to students' creative thinking skills}

Table 4. Average

\begin{tabular}{lll}
\hline \multicolumn{1}{c}{ Group } & \multicolumn{1}{c}{ Test } & Average \\
\hline \multirow{2}{*}{ Experiment } & Pretest & 32,25 \\
\cline { 2 - 3 } & Posttest & 81,11 \\
\cline { 2 - 3 } & $\mathrm{N}$-gain & 71,24 \\
\hline Control & Pretest & 30,64 \\
\cline { 2 - 3 } & Posttest & 68,18 \\
\cline { 2 - 3 } & N-gain & 54,06 \\
\hline
\end{tabular}

According to the data, the average of $\mathrm{N}$-gain (71.24\%) in experiment class using LKPD based on the SETS approach is higher (quite effective) than the control class $(54.06 \%)$ using 
textbooks (less effective). To verify an average of each group, it necessary to conduct test (Table 5).

Table 5. The Result

\begin{tabular}{lc}
\hline \multicolumn{1}{c}{ Group } & Paired Sample T-Test \\
\hline Experiment & 0,000 \\
\hline Control & 0,000 \\
\hline
\end{tabular}

Based on the results of data it has differences between creative thinking skills on pretest and posttest. To verify that the LKPD based on the SETS approach is effective, it is necess ary to conduct test (Table 6).

Table 6. The Result

\begin{tabular}{lc}
\hline \multicolumn{1}{c}{ Group } & Sample T \\
\hline Pretest & 0,572 \\
\hline Posttest & 0,000 \\
\hline N-gain & 0,000 \\
\hline
\end{tabular}

Analy sis of the test data, it shows that for pretest data between creatives experiment and control. Thus, LKPD based on the SETS approach was more effective to be used than textbook.

\subsection{Effectiveness of LKPD bas ed on SETS approach to students' critical thinking skills}

Table 7. Averages

\begin{tabular}{lll}
\hline \multicolumn{1}{c}{ Group } & \multicolumn{1}{c}{ Test } & Average \\
\hline \multirow{2}{*}{ Experiment } & Pretest & 38,75 \\
\cline { 2 - 3 } & Posttest & 82,29 \\
\cline { 2 - 3 } & N-gain & 69,23 \\
\hline Control & Pretest & 34,50 \\
\cline { 2 - 3 } & Posttest & 68,57 \\
\cline { 2 - 3 } & $\mathrm{N}-$ gain & 50,99 \\
\hline
\end{tabular}

According the data, it shows the average of $\mathrm{N}$-gain $(69.23 \%)$ in experiment clas s using LKPD based on the SETS approach is higher (quite effective) than the control clas s (50.99\%) using textbooks (les s effective). To verify an average of each group (experiment and control) (Table 8).

Table 8. The Result

\begin{tabular}{lc}
\hline \multicolumn{1}{c}{ Group } & Score \\
\hline Experiment & 0,000 \\
\hline Control & 0,000 \\
\hline
\end{tabular}


Data have significant differences between critical thinking on pretest and posttest. To verify that the LKPD based on the SETS approach is effective, it is necessary to conduct test (Table 9).

Table 9.The Result o

\begin{tabular}{lc}
\hline \multicolumn{1}{c}{ Group } & Sample T \\
\hline Pretest & 0,206 \\
\hline Posttest & 0,000 \\
\hline N-gain & 0,000 \\
\hline
\end{tabular}

Analysis the independent test, it shows experiment are difference of critical thinking skills. Then, for pos ttest and N-gain data, the results show that difference two groups. Thus, it was concluded that the LKPD based on the SETS approach was more effective to be used than using a textbook.

\section{Conclusion}

The LKPD with SETS approaches is appropriate and has a role as an innovative learning resource to increase the learning process. Then, LKPD based on SETS approach could train creative and critical skills of students and LKPD was quite effectively used in learning activities.

\section{Acknowledgments}

Res earchers would like to thank profusely to supervisors, Arwin Surbakti and Rochmiyati for who taugh, educated and encouragement to finish writing this article. The researcher would like to thank for educators and for clas s V of UPT SDN 6 Sumberejo, Indonesia and also to fellow Teachers of Teachers of Elementary Teachers who also contributed in encouraging them to complete this research.

\section{Reference}

[1] Susanto, Ahmad. Teori Belajar dan Pembelajaran di Sekolah Dasar. Jakarta: Kencana Prenadamedia Group. pp. 322. (2014)

[2] Roekel, Dennis Van.Preparing 21st Century Students for a Global Society. (Online). http://www.nea.org/assets/docs/A-Guide-to-Four-Cs.pdf. Diaksespada 05 Desember 2018. Pukul 16:00 WIB. (2012)

[3] Richard, F., Mellander, C., \& King, K. The Global Creativity Index 2015. Toronto. (2015)

[4] Puspendik. TIMSS Infographic. (Online). http://www.acdp-indonesia.org/wpcontent/uploads/2017/01/TIMSS-infographic.pdf. Diaksespada 25 September 2018. Pukul 21.32 WIB. (2016)

[5] Amyana, I.B. PengembanganPetaPikiranUntukPeningkatkanKecakapanBerpikirKreatifSiswa. JurnalPendidikandanPengajaran, No. 3 TH. XXXX. pp 670-683. (2007)

[6] Mufiannoor, E. MelatihkanKemampuanBerpikirKreatif Dan PemahamanKonsepDenganPembelajaranBerbasisInkuiriTerbimbingPadaMateriInteraksiMakhlukHidu pDenganLingkungan. JurnalPenelitianPendidikanSains. 5(2), pp 934-941. (2016) 
[7] Khasanah, N. SETS (Science, Environmental, Technology and Society) sebagaiPendekatanPembelajaran IPA Modern padaKurikulum 2013. Makalahdisampaikandalam Seminar NasionalKonservasidanPemanfaat anSumberDayaAlam di FKIP UNS. (2015)

[8] Poedjiadi, A. SainsTeknologiMasyarakat (Model PembelajaranKontekstualBermuatanNilai). Bandung: PT. RemajaRosdakarya. pp. 167. (2010)

[9] Penn State. About STS. (Online). http://www.engr.psu.edu/sts/abaut.htm. Diaksespada 28 November 2018. Pukul 20.40 WIB. (2006)

[10] Lee, Mee-Kyeong and Erdogan, Ibrahim. The Effect of Science-Technology-Society Teaching on Students' Attitudes toward Science and Certain Aspects of Creativity. International Journal of Science Education. Vol. 29, No.11, pp. 1315-1327.(2007)

[11] Prastowo, Andi. PanduanKreatifMembuatBahan Ajar Inovatif. Yogyakarta: Diva Press. (2015)

[12] Wahid, Herniwati. Penerapan Model GrupInvestigasiBervisi SETS di SekolahDasar. Prosiding Seminar Nasional. Vol. 03, No. 1. ISSN 2443-1109. (2017)

[13] Harnani, Susi \&Suyatna, Agus. LKS Pemanasan Global Bervisi SETS BerorientasiKontruktivistikuntukMeningkatkanKemampuanBerpikirKritis. Prosiding Seminar NasionalFisika (E-Journal). Vol. IV. e-ISSN: 2476-9398 p-ISSN: 2339-0654. (2015)

[14] Purwanto. Evaluasi Hasil Belajar. Surakarta: Pustaka Belajar. pp. 224. (2009)

[15] Akbar, Sa'dun. Instrumen Perangkat Pembelajaran. Bandung: Rosdakarya. pp. 165. (2013)

[16] Meltzer, D.E. The Relationship between Mathematics Preparation and Conceptual Learning Grains in Physics: A Possible "Hidden Variable" in Diagnostice Pretest Scores. American Journal Physics. Vol 70 No 12, pp. 27. (2002)

[17] Hake, R, R. Analyzing Change/Gain Scores. AREA-D American Education Research Association's Devision D: Measurement and Research Methodology. (1999) 